\title{
Biochar successfully replaces activated charcoal for in vitro culture of two white poplar clones reducing ethylene concentration
}

\author{
Sara Di Lonardo - Francesco Primo Vaccari - Silvia Baronti • \\ Maurizio Capuana - Laura Bacci · Francesco Sabatini • \\ Maurizio Lambardi $\cdot$ Franco Miglietta
}

Received: 8 November 2011 / Accepted: 22 August 2012/Published online: 4 September 2012

(C) Springer Science+Business Media B.V. 2012

\begin{abstract}
Biochar (BC) is a carbon rich product resulting from the biomass pyrolysis process and there have been no reports until now on $\mathrm{BC}$ effects in tissue cultures as a suitable substitute for activated charcoal (AC). The results of an experiment on two clones of white poplar (Populus alba L.) grown in culture media with different amounts of $\mathrm{BC}\left(0,0.5\right.$ and $\left.1.5 \mathrm{~g} / \mathrm{dm}^{3}\right)$ showed that its addition did not damage the plants and there were no significant differences comparing the data obtained for the same concentrations of AC. Both BC and AC addition was shown to increase root dry biomass and number of roots per shoot and these effects appeared to be independent of genotype and concentrations of the added products. A greater elongation was also recorded for shoots grown on a substrate containing $\mathrm{BC}$ than those grown on media without BC. These effects did not seem to be caused by darkening due to the addition of $\mathrm{BC}$ as there are no significant differences between the temperatures of the different culture media, but are
\end{abstract}

S. Di Lonardo $(\bowtie) \cdot$ F. P. Vaccari · S. Baronti · L. Bacci .

F. Sabatini - F. Miglietta

Institute of Biometeorology (IBIMET), National Research

Council (CNR), via Giovanni Caproni 8, 50145 Florence, Italy

e-mail: s.dilonardo@ibimet.cnr.it

M. Capuana

Institute of Plant Genetics (IGV), National Research Council

(CNR), via Madonna del Piano 10, 50019 Sesto Fiorentino,

FI, Italy

M. Lambardi

Trees and Timber Institute (IVALSA), National Research

Council (CNR), via Madonna del Piano 10,

50019 Sesto Fiorentino, FI, Italy

F. Miglietta

FoxLab (Forest and Wood), Fondazione E. Mach (Iasma),

via E. Mach 1, 38010 San Michele all'Adige, TN, Italy probably due to the adsorption of molecules such as ethylene. Indeed, during the experiment, the hormone concentration in the atmosphere was lower in vials containing the media with $\mathrm{BC}$ than the BC-free ones after 14 and 21 days: the lower amount of ethylene in the medium with BC could explain the difference in shoot elongation and the abundant root biomass since high ethylene concentration could inhibit organogenesis.

Keywords Black carbon - Effects - Temperature · Ethylene $\cdot$ Populus alba L.
Abbreviations
AC Activated carbon
BC Biochar
QRC Querce clone
VIL Villafranca clone
WPM Woody plant medium

\section{Introduction}

Activated carbon (AC) is manufactured by heating carbonaceous material at a high temperature (above $500{ }^{\circ} \mathrm{C}$ ) over long periods of time $(>10 \mathrm{~h})$ and finally activated with energy wasteful processes. AC, produced from wood, wood waste, paper-mill waste liquors and peat (El-Hendawy et al. 2001) is often used in plant tissue culture: it is well known that it may improve cell growth and development (Pan and Van Staden 1998) and better growth responses of plant tissues are generally associated with the addition of $\mathrm{AC}$ to both liquid and semi-solid media (Anagnostakis 1974; Fridborg and Eriksson 1975; Horner et al. 1977; Weatherhead et al. 1978; Peck and Cumming 1986; Bon et al. 1988; Zaghmout and Torello 1988). AC has been 
used to promote somatic embryogenesis (Buccheim et al. 1989; Andrade and Merkle 2005; Zouine et al. 2005), androgenesis (Johansson 1986; Nomizu et al. 2004; Laura et al. 2006), rooting (Sul and Korban 2004; Loc et al. 2005), shoot and root elongation (Mohamed-Yasseen 2001; Sul and Korban 2005), bulb formation (Peck and Cumming 1986; Vishnevetsky et al. 2003) and to inhibit tissue browning (Mohamed-Yasseen 1994; Mohamed-Yasseen et al. 1995). For an extensive review on the effects of AC in tissue culture, see e.g. Thomas (2008). These effects may be due to various reasons, e.g. the darkening (Pan and Van Staden 1998) and aeration of culture media (Dumas and Monteuuis 1995; Mohamed-Yasseen 2001), the release of substances naturally present in AC which promote growth (Misson et al. 1983) and the adsorption of certain molecules which later become available to plants (Johansson and Eriksson 1977; Johansson et al. 1990; Fridborg et al. 1978). However these mechanisms are largely unclear. Johansson et al. (1982) and Johansson (1983) demonstrated that the stimulatory effect of AC on plant growth may be caused by the adsorption of plant hormones, phenolic compounds and/or inhibitory substances from the nutrient solution, such as 6-benzyladenine and, in particular, ethylene. Ethylene, a gaseous plant hormone that can inhibit shoot elongation (Guzmán and Ecker 1990), has been well studied in relation to vegetative plant growth, seed dormancy and germination processes (Abeles et al. 1992), but only few studies have focused on the relationships between charcoal, ethylene and those physiological processes. In a study on Nicotiana tabacum L., Horner et al. (1977) proposed that AC could be able to adsorb ethylene released by the medium and by plant nodes, reducing its accumulation in closed culture vessels and thus increasing growth.

One very interesting option in tissue culture may be the substitution of AC with biochar (BC), a carbon-rich material similar in appearance to charcoal, produced by pyrolysis. The term $\mathrm{BC}$ was originally associated with a specific type of production, known as 'slow pyrolysis', a type of pyrolysis in which oxygen is absent, heating rates are relatively slow and peak temperatures relatively low. However, the term $\mathrm{BC}$ has been extended to products of short duration pyrolysis at higher temperatures known as 'fast pyrolysis' or to products of pyrolytic stoves. Due to its chemical structure, $\mathrm{BC}$ exhibits a long mean residence time in soil, estimated between 1,000 and 10,000 years (Lehmann et al. 2008; Liang et al. 2008; Kuzyakov et al. 2009; Major et al. 2010). Given this recalcitrance, BC is beginning to receive attention as a potential soil carbon sequestration method (Lehmann 2007) and has recently been proposed as a promising management option to reduce atmospheric $\mathrm{CO}_{2}$ concentration (Smith et al. 2010). Moreover, the $\mathrm{BC}$ application to soil improves its physical and chemical characteristics (Chan et al. 2007) and hydraulic properties (Lehmann and Joseph 2009; Woolf et al. 2010). Many studies have recently shown the positive effect of the addition of $\mathrm{BC}$ to soil on field crop growth (Lehmann et al. 2003; Lehmann and Rondon 2006; Yamato et al. 2006; Chan et al. 2007; Rondon et al. 2007; Kimetu et al. 2008; Sinclair et al. 2008; Steiner et al. 2008; Van Zwieten et al. 2008; Blackwell et al. 2009; Baronti et al. 2010; Gaskin et al. 2010; Noguera et al. 2010; Vaccari et al. 2011). Furthermore, it has been proved that BCs are characterized by high affinity for organic contaminants (Cao et al. 2009; Kookana 2010; Wang et al. 2010; Sun et al. 2011a, b) and heavy metals (Beesley and Marmiroli 2011) because of their adsorptive capacity, thus in other contexts these materials may potentially be an alternative for AC (Oleszczuk et al. 2012). No data are reported for the use and effects of $\mathrm{BC}$ in in vitro cultures.

This paper describes the effects of the in vitro inclusion of $\mathrm{BC}$ in the medium of two shoot cultured clones of white poplar (Populus alba L.), in comparison with the traditional use of AC. Particular attention has been paid to evaluating the interactions among root and shoot growth, medium temperature, which could be affected by the dark color of $\mathrm{BC}$ and $\mathrm{AC}$, and ethylene accumulation in the vial atmosphere, in order to ascertain some possible action mechanisms of BC on cultured shoots.

\section{Materials and methods}

Plant material and experimental conditions

In vitro proliferating shoots of a commercial and an autochthonous Populus alba L. clone, Villafranca (VIL) and Querce (QRC), respectively, were subcultured on woody plant medium (WPM; Lloyd and McCown 1980). Media contained $20 \mathrm{~g} / \mathrm{dm}^{3}$ of sucrose and $0.2 \mathrm{mg} / \mathrm{dm}^{3}$ of benzyladenine and were solidified with $7.2 \mathrm{~g} / \mathrm{dm}^{3}$ of agar (B\&V, Reggio Emilia, Italy), at pH 5.5, in $100 \mathrm{~cm}^{3}$ babyfood glass jars (Sigma-Aldrich, Milano, Italy). Media were sterilized by autoclaving at $121{ }^{\circ} \mathrm{C}$ and $108 \mathrm{kPa}$ for $20 \mathrm{~min}$. Shoots originated from shoot tips collected from in vivo adult trees of the above-mentioned clones were multiplied by axillary bud proliferation, according to Confalonieri et al. (2003), with 4-week subculturing. The jars were incubated in a growth chamber at $23 \pm 1{ }^{\circ} \mathrm{C}$ with a 16-h photoperiod (light intensity, $40 \mu \mathrm{mol} \mathrm{m}{ }^{-2} \mathrm{~s}^{-1}$ ).

Before the treatments, shoots were transferred to phytohormone-free WPM medium. After four weeks, welldeveloped shoots were cut to uniform size (two internodes; $1.5 \mathrm{~cm}$ tall) and transferred to phytohormone-free WPM medium containing $\mathrm{BC}(1.5 \mathrm{~g}$ [BC1] and $0.5 \mathrm{~g}$ [BC2] per 
$\left.\mathrm{dm}^{3}\right)$ and $\mathrm{AC}\left(1.5 \mathrm{~g}[\mathrm{AC} 1]\right.$ and $0.5 \mathrm{~g}$ [AC2] per $\left.\mathrm{dm}^{3}\right)$ to evaluate rooting capacity. $\mathrm{BC}$ was crushed to a powder before being added to the medium in order to increase the area/volume ratio and have similar size to $\mathrm{AC}$ particles $(<2 \mathrm{~mm})$. The color of medium with $\mathrm{BC}$ was similar to that with AC (Fig. 1). The evaluation of shoots on media without $\mathrm{AC}$ or $\mathrm{BC}$ (controls or $\mathrm{C}$ ) was included in the experiment. Twenty plants per clone per concentration replicated three times (four glass jars per treatment per clone) were used in the experiments. After 30 days, the shoots were gently extracted from the medium and separated into shoots and roots. The following parameters were measured: (1) weight and length of shoots and (2) weight and number of roots. Roots and shoots were oven-dried at $80{ }^{\circ} \mathrm{C}$ for $24 \mathrm{~h}$ after which dry weights were recorded.

\section{Chemical analysis}

$\mathrm{BC}$ was obtained from poplar biomass using a pyrolitic stove that has a coaxial burner with a swirl pattern, resulting in highly efficient syngas combustion and heat transfer. The temperature of pyrolysis, measured inside the stove with thermocouples (K type, COD. 406-486, TC Direct Srl) inserted in burning poplar biomass, was $550{ }^{\circ} \mathrm{C}$. $\mathrm{AC}$ is a commercial product purchased from Carlo Erba Reagenti SpA company (Cod. 7440-44-0).

Chemical analyses were performed on $\mathrm{BC}$ and $\mathrm{AC}$ (Table 1). $\mathrm{C}$ and $\mathrm{N}$ contents were determined using a CHN Elemental Analyzer (Carlo Erba Instruments, mod 1500 series 2). The dry samples were acid-digested in a microwave oven (CEM, MARSXpress) according to the EPA method 3052 (USEPA 1995). The solutions obtained after mineralization were filtered with $0.45 \mu \mathrm{m}$ PTFE and then diluted. Macro and microelements were determined by acid digestion of $0.05 \mathrm{~g}$ in $5 \mathrm{~cm}^{3}$ of nitric acid $\left(\mathrm{HNO}_{3}\right)$; after $30 \mathrm{~min}, 2 \mathrm{~cm}^{3}$ of perchloric acid $\left(\mathrm{HClO}_{4}\right)$ were added according to Miller (1998). The digested samples were first centrifuged and then filtered through a ceramic filter. The samples were subsequently analyzed with an ICP-OES
Table 1 Characteristics of BC and AC used

\begin{tabular}{lcc}
\hline Properties & BC & AC \\
\hline Total C (\%) & 78.69 & 81.06 \\
Total N (\%) & 0.11 & 0.34 \\
$\mathrm{P}\left(\mathrm{mg} \mathrm{kg}^{-1}\right)$ & 405.2 & 189.5 \\
$\mathrm{~K}\left(\mathrm{mg} \mathrm{kg}^{-1}\right)$ & 1584.0 & 742.4 \\
$\mathrm{Ca}\left(\mathrm{mg} \mathrm{kg}^{-1}\right)$ & 7534.0 & 7649.0 \\
$\mathrm{Mg}\left(\mathrm{mg} \mathrm{kg}^{-1}\right)$ & 714.0 & 614.03 \\
$\mathrm{pH}\left(1: 4 \mathrm{H}_{2} \mathrm{O}\right)$ & 7.0 & 7.2 \\
\hline
\end{tabular}

spectrophotometer (IRIS Intrepid II XSP Radial, Thermo Fisher Scientific). The $\mathrm{pH}$ values were measured in water solution (1:4).

Measurements of culture media temperature

The temperature of the culture media was measured by using $1.5 \mathrm{~mm}$ diameter-micro-thermistors (Ntc, negative temperature coefficient-thermistors of $10 \mathrm{kOhm}$; PR503J2, US Sensor Corp.) with low thermal inertia and fast time response. The thermistors were previously crosscalibrated and soaked for $20 \mathrm{~min}$ in $1.4 \%$ sodium hypochlorite solution and then used to detect the temperature of three different culture media in three different jars: (1) WPM; (2) WPM with $1.5 \mathrm{~g} / \mathrm{dm}^{3}$ of BC added (BC1); (3) WPM with $0.5 \mathrm{~g} / \mathrm{dm}^{3}$ of BC added (BC2). Each $100 \mathrm{~mm}$ diameter glass jar contained three micro-thermistors connected to a data-logger (mod. Delta-T DL2, Delta-T Devices, UK) for 2 days; all temperature data were collected with a time acquisition interval of $10 \mathrm{~min}$.

\section{Determination of ethylene production}

In vitro shoot cultures of VIL clone were used as source of explants, consisting of $1.5-\mathrm{cm}$ shoots with two internodes and no roots. After isolation, shoots were transferred to phytohormone-free WPM medium for 2 days in order to remove the ethylene production caused by the cuts during

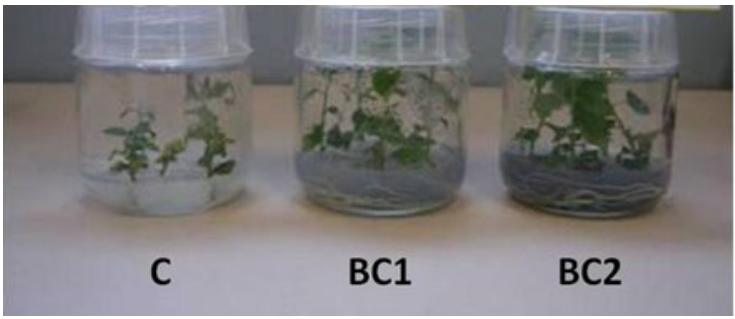

Fig. 1 Shoots of Populus alba L. clones (Villafranca) grown on different media after 30 days of culture. $\mathrm{C}$, control; $\mathrm{BC} 1$, medium with $1.5 \mathrm{~g} / \mathrm{dm}^{3}$ of $\mathrm{BC}$ added; $\mathrm{BC} 2$, medium with $0.5 \mathrm{~g} / \mathrm{dm}^{3}$ of $\mathrm{BC}$

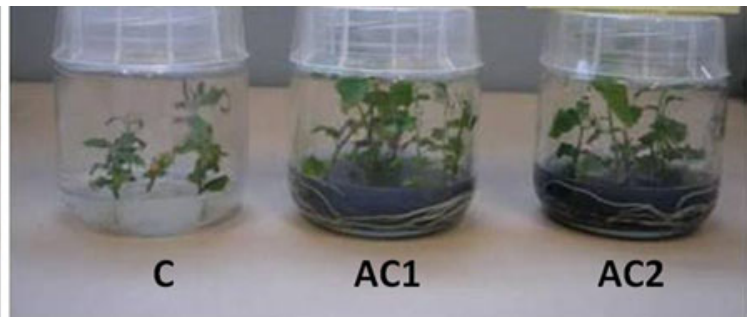

added; AC1, medium with $1.5 \mathrm{~g} / \mathrm{dm}^{3}$ of AC added; AC2, medium with $0.5 \mathrm{~g} / \mathrm{dm}^{3}$ of $\mathrm{AC}$ added 
subculturing. The shoots were then transplanted singly into $20 \mathrm{~cm}^{3}$ vials containing WPM (in the text WPM $+\mathrm{P}$, where $\mathrm{P}$ stands for plant) and WPM with $1.5 \mathrm{~g} / \mathrm{dm}^{3}$ of $\mathrm{BC}$ added (WPM $+\mathrm{P}+\mathrm{BC} 1$ ). Twelve shoots were considered per treatment. Vials with only WPM (WPM) and WPM with $1.5 \mathrm{~g} / \mathrm{dm}^{3}$ of BC added (WPM + BC1) were included in the experiment to evaluate ethylene accumulation in the vial atmosphere. Vials were capped with airtight serum caps (Sigma Chemical Co., St. Louis, MO, USA), in order to completely seal the containers (Joy et al. 1991). All flasks were maintained in a growth chamber at the conditions previously described.

For the determination of ethylene accumulation inside the vials, gas samples $\left(1 \mathrm{~cm}^{3}\right)$ were withdrawn from the atmosphere of the containers and injected into a PerkinElmer Autosystem Gas Chromatograph (Boston, MA, USA), equipped with a flame ionization detector and a Poropak Q column (80-100 Mesh). Column, injector and detector temperatures were 50,50 and $250{ }^{\circ} \mathrm{C}$, respectively. Nitrogen was the carrier gas at 20 psi. Ethylene concentration was determined in comparison to a standard of $0.01 \mathrm{~cm}^{3} / \mathrm{dm}^{3}$.

\section{Statistical analysis}

Statistical analysis was carried out with one-way and twoway analysis of variance (ANOVA) using the statistical program Statistica 6.0 (StatSoft, 2003). Mean separation was obtained by means of the Tukey HSD test. Clones and treatments were considered as independent variables. Means were considered different at a probability level of $P \leq 0.05$.

\section{Results and discussion}

After 30 days from transferring onto culture medium, all shoot cultures had rooted (Fig. 1). The root dry biomass of the two white poplar clone shoots, VIL and QRC, treated with $\mathrm{BC}$ and $\mathrm{AC}$ at the two different concentrations (0.5 and $1.5 \mathrm{~g} / \mathrm{dm}^{3}$ ) differed significantly from the control (14.5-18.1 mg against 5.6-7.6 mg of non-treated shoots) (Fig. 2a). No differences were detected between BC and AC treatments nor between the two genotypes $(P \leq 0.05)$. Indeed both VIL and QRC responded in a similar way to both treatments (AC and $\mathrm{BC}$ ) and at different concentrations, since average values of root dry biomass did not result as significantly different $(15.8 \mathrm{mg}$ [QRC microshoots in $\mathrm{AC} 1$ ], $14.5 \mathrm{mg}$ [QRC microshoots in $\mathrm{AC} 2$ ], $15.9 \mathrm{mg}$ [QRC microshoots in $\mathrm{BC} 1], 16.4 \mathrm{mg}$ [QRC microshoots in $\mathrm{BC} 2], 16.9 \mathrm{mg}$ [VIL microshoots in AC1], $15.6 \mathrm{mg}$ [VIL microshoots in AC2], $16.3 \mathrm{mg}$ [VIL microshoots in $\mathrm{BC} 1]$ and $18.1 \mathrm{mg}$ [VIL microshoots in BC2]) (Fig. 2a).
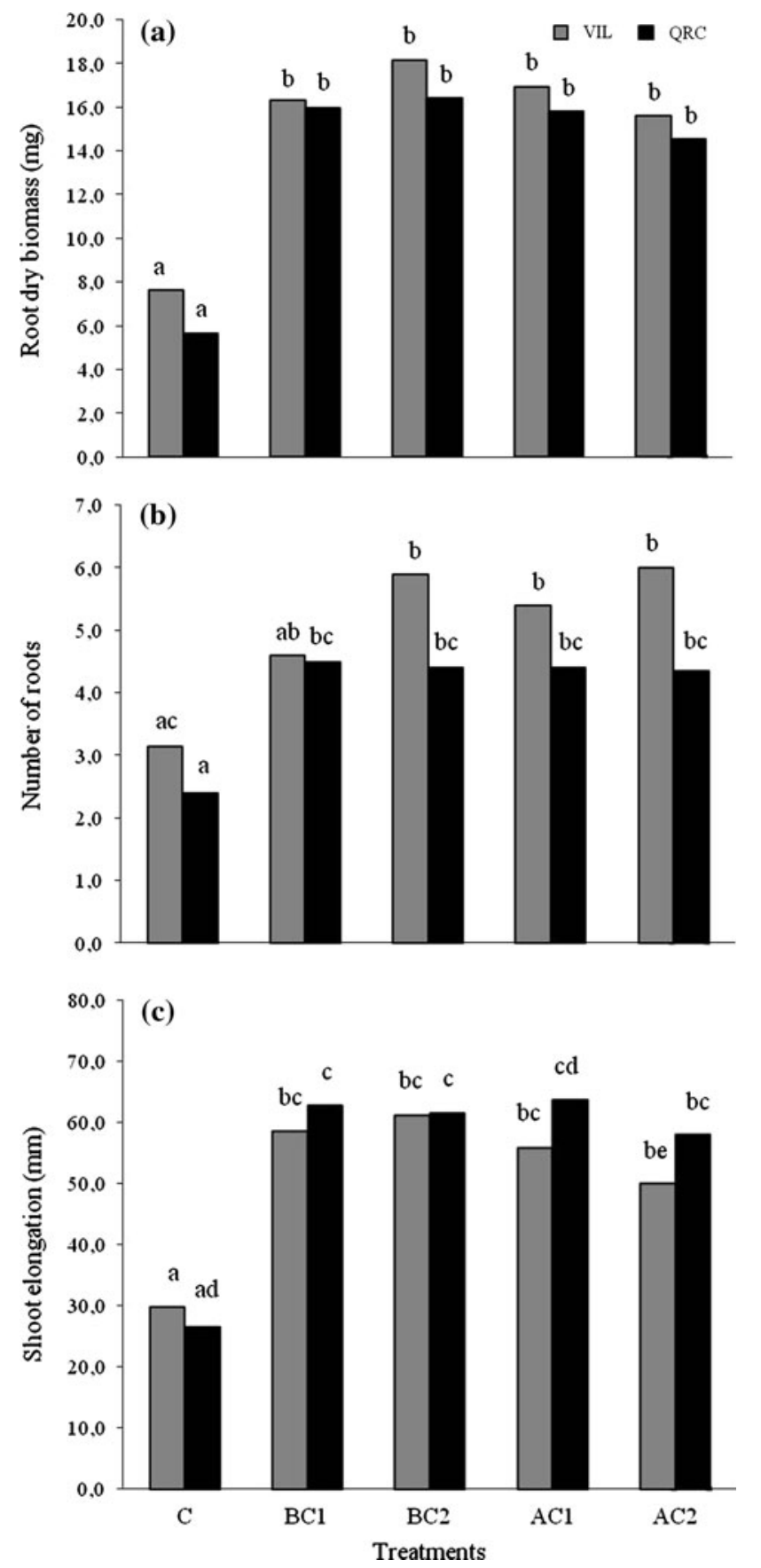

Fig. 2 Root dry biomass (mg) (a), number of roots (b) and shoot elongation (mm) (c) of $P$. alba clones after BC and AC treatments. Values are means of at least twenty values; significant differences between the means (at least $P \leq 0.05$, according to ANOVA) within one clone appear with different letters. $\mathrm{C}$, control; $\mathrm{BC} 1$, medium with $1.5 \mathrm{~g} / \mathrm{dm}^{3}$ of $\mathrm{BC}$ added; $\mathrm{BC} 2$, medium with $0.5 \mathrm{~g} / \mathrm{dm}^{3}$ of $\mathrm{BC}$ added; $\mathrm{AC} 1$, medium with $1.5 \mathrm{~g} / \mathrm{dm}^{3}$ of $\mathrm{AC}$ added; $\mathrm{AC} 2$, medium with $0.5 \mathrm{~g} /$ $\mathrm{dm}^{3}$ of AC added; VIL, Villafranca clone; QRC, Querce clone

Whereas no significant differences were detected for shoots in any of treatments (data not shown).

A positive effect of $\mathrm{AC}$ and $\mathrm{BC}$ was also detected on the rootability of shoots, regardless of the concentration in 
almost all treatments (Fig. 2b). It resulted in a significant increase in number of roots; indeed shoots of both clones growing on media with $\mathrm{AC}$ or $\mathrm{BC}$ produced more roots (4-6) on average than the control $(2-3)(P \leq 0.05)$. A similar effect was reported by Dumas and Monteuuis (1995) for juvenile Pinus pinaster L. explants cultured in the presence of AC. Influence on rooting was also reported by Firoozabady et al. (2006); in their work the addition of $\mathrm{AC}$ considerably enhanced the rooting ability of transgenic shoots in pineapple.

$\mathrm{AC}$ was also found to induce shoot maturation and elongation, as observed in cotton (Gossypium hirsutum) cultured on Murashige and Skoog medium fortified with $3 \mathrm{~g} / \mathrm{dm}^{3}$ of AC (Hemphill et al. 1998) and in corn shoots cultured in a medium with $5 \mathrm{~g} / \mathrm{dm}^{3}$ of $\mathrm{AC}$ and $\left[{ }^{3} \mathrm{H}\right]$ marked gibberellin (Mohamed-Yasseen 2001).

Data in Fig. 2c show that in general both $\mathrm{AC}$ and $\mathrm{BC}$ treatments enhanced shoot length by about $100 \%$ $(P \leq 0.05)$ for $\mathrm{QRC}$ in $\mathrm{BC} 1(27 \mathrm{~mm}$ of $\mathrm{C}$ vs. $63 \mathrm{~mm}$ of $\mathrm{BC} 1)$, in $\mathrm{BC} 2(27 \mathrm{~mm}$ of $\mathrm{C}$ vs. $61 \mathrm{~mm}$ of $\mathrm{BC} 2), \mathrm{AC} 1$ (27 $\mathrm{mm}$ of $\mathrm{C}$ vs. $64 \mathrm{~mm}$ of $\mathrm{AC} 1)$ and $\mathrm{AC} 2(27 \mathrm{~mm}$ of $\mathrm{C}$ vs. $58 \mathrm{~mm}$ of AC2) even if shoot dry biomass was not significantly different (data not shown). The length was always greater than the control $(P \leq 0.05)$ for VIL plants grown on media with $\mathrm{BC} 1(30 \mathrm{~mm}$ of $\mathrm{C}$ vs. $59 \mathrm{~mm}$ of $\mathrm{BC} 1), \mathrm{BC} 2(30 \mathrm{~mm}$ of C vs. $61 \mathrm{~mm}$ of $\mathrm{BC} 2), \mathrm{AC} 1(30 \mathrm{~mm}$ of $\mathrm{C}$ vs. $56 \mathrm{~mm}$ of $\mathrm{AC} 1)$ and $\mathrm{AC} 2(30 \mathrm{~mm}$ of $\mathrm{C}$ vs. $50 \mathrm{~mm}$ of $\mathrm{AC} 2$ ).

The overall average temperatures measured by the micro-thermistors inserted directly in the media without shoots are indicated in Table 2. No significant differences were detected among the three tested media throughout the experimental period. We can therefore assume that the grey color of the medium did not affect the temperature.

White poplar shoots produced ethylene which accumulated in the culture vials (Fig. 3). The maximum mean amount observed was about $2.46 \mathrm{ppm}$ after 28 days from the beginning of the experiment. No initial burst of ethylene was detected but there was a relevant rise in the amount produced from the 7th day associated with the rapid growth of the shoots (data not shown).

Table 2 Means of temperatures of three different culture media

\begin{tabular}{ll}
\hline Treatment & ${ }^{\circ} \mathrm{C}$ \\
\hline WPM & $23.2 \pm 0.43 \mathrm{a}$ \\
$\mathrm{WPM}+\mathrm{BC} 1$ & $23.2 \pm 0.43 \mathrm{a}$ \\
$\mathrm{WPM}+\mathrm{BC} 2$ & $23.1 \pm 0.42 \mathrm{a}$ \\
\hline
\end{tabular}

Significant differences between the means (at least $P \leq 0.05$, according to ANOVA) appear with different letters. WPM, woody plant medium, WPM $+\mathrm{BC} 1$, woody plant medium with $1.5 \mathrm{~g} / \mathrm{dm}^{3}$ of $\mathrm{BC}$ added; WPM + BC2, woody plant medium with $0.5 \mathrm{~g} / \mathrm{dm}^{3}$ of BC added

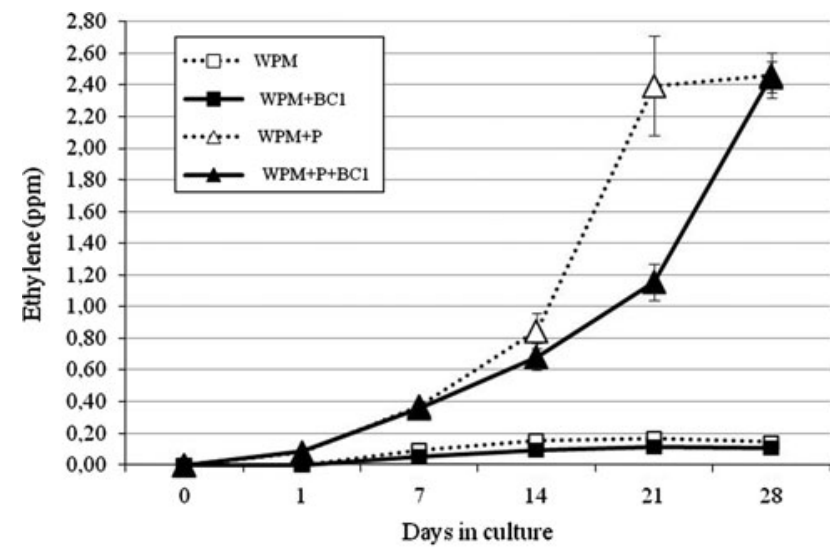

\begin{tabular}{|c|c|c|c|c|}
\hline Day in culture & WPM & WPM+BC1 & WPM+P & WPM+P+BC1 \\
\hline 0 & a & a & a & a \\
\hline 1 & a & a & b & b \\
\hline 7 & a & a & b & b \\
\hline 14 & a & a & b & c \\
\hline 21 & a & a & b & c \\
\hline 28 & a & a & b & b \\
\hline
\end{tabular}

Fig. 3 Ethylene content (ppm). Values are mean \pm standard error; significant differences between the means (at least $P \leq 0.05$, according to ANOVA) appear with different letters in every row of the enclosed table. Open square, WPM woody plant medium; filled square, $\mathrm{WPM}+\mathrm{BC} 1$, woody plant medium $+1.5 \mathrm{~g} / \mathrm{dm}^{3}$ of $\mathrm{BC}$; open triangle, $\mathrm{WPM}+\mathrm{P}$, woody plant medium + plant; filled triangle, $\mathrm{WPM}+\mathrm{P}+\mathrm{BC} 1$, woody plant medium + plant $+1.5 \mathrm{~g} / \mathrm{dm}^{3}$ of BC

The addition of $\mathrm{BC} 1$ to the culture medium markedly influenced ethylene concentration in the shoot-containing vials. Indeed, in the central period of subculture (from day 14 to day 21) a significant reduction of ethylene accumulation in the atmosphere of vials containing shoots on $\mathrm{WPM}+\mathrm{BC} 1$ was observed, in comparison with the shoots that were cultured on $\mathrm{BC}$-free medium. It is possible to hypothesize the adsorption of ethylene by $\mathrm{BC}$, as already reported for AC that seemed not only to adsorb ethylene (Mensuali-Sodi et al. 1993; Horner et al. 1977; Fridborg et al. 1978) but also other substances e.g. growth regulators and inhibitory molecules (nicotinic acid, Weatherhead et al. 1978; iron chelate and folic acid, Johansson et al. 1990). We can also suppose that $\mathrm{BC}$ is similar to $\mathrm{AC}$ because the ethylene curve was similar to Mensuali-Sodi et al. (1993), even if the paper was on AC. No report exists about inhibit growth regulators/inhibitory molecules and $\mathrm{BC}$ but many papers report that $\mathrm{BC}$ could adsorb molecules such as pesticides (for this topic, see e.g. Hale et al. 2011; Sun et al. 2011a, b; Song et al. 2012; Sopeña et al. 2012; Sun et al. 2012a, b; Uchimiya et al. 2012) and heavy metals (see e.g. Park et al. 2011; Borchard et al. 2012). Of course it has been reported that the effect of $\mathrm{AC}$ on ethylene adsorption is dependent on culture conditions, such as container volume and shape, medium volume and surface exposed to the inner atmosphere (Mensuali-Sodi et al. 1993) but in the present study ethylene decrease was also evident in $20 \mathrm{~cm}^{3}$ vials that had a low agar surface. The low BC quantity in the 
medium also seemed to account for a time-limited adsorption of the gaseous hormone, as ethylene concentration was similar after 28 days in both the BC-containing and BC-free vials. Vials with only WPM (WPM) and vials containing WPM with BC added (WPM + BC1) showed no ethylene accumulation, differently from what was observed by Spokas et al. (2010) who also found ethylene production analyzing sterile soil amended with BC. Ethylene production has been observed in some types of biochar (Spokas et al. 2010) and this only apparently contradicts the results reported in this study, where ethylene absorption was instead detected. Such a discrepancy may in fact be reconciled considering that the ethylene production reported by Spokas et al. (2010) was only associated to non-woody feedstocks and decreased with increasing pyrolysis temperature above $400{ }^{\circ} \mathrm{C}$ since the properties of the resulting biochar vary as a function of the feedstock and conditions of the pyrolysis (Sensöz 2003; Guerro et al. 2005). This suggests the co-occurrence of ethylene emission/absorption capacity in biochar and the fact that in some types of biochar produced at high temperature and from wood feedstocks the latter effect definitely prevails. This is of importance for in vitro cultures where high concentrations of this gas may have negative effects on plant organogenesis since high ethylene concentration could inhibit organogenesis (Guzmán and Ecker 1990). Moreover, recent studies (Spokas et al. 2011) reported that a wide range of organic volatile compounds (VOCs) are released by biochar and the hypothesis that some of those VOCs may have an effect on growth cannot be ruled out (Simms and Rausher 1987; Ryu et al. 2003; Kloepper et al. 2004; Baldwin et al. 2006; Zhang et al. 2007).

\section{Conclusion}

The data reported in this paper can have practical importance for future applications of BC in in vitro cultures. Our results showed that the charcoal concentrations for both $\mathrm{AC}$ and $\mathrm{BC}\left(0.50\right.$ and $\left.1.50 \mathrm{~g} / \mathrm{dm}^{3}\right)$ have the same effects on poplar tissue culture since no major differences were found between the two types of treatment. No negative effects of $\mathrm{BC}$ were detected for white poplar shoot cultures while the addition of $\mathrm{AC}$ or $\mathrm{BC}$ was shown to improve the potential for rooting in terms of enhancement of the dry biomass as well as the number of roots and these effects appeared to be independent of genotype and concentrations used in our experiments. There was no darkening effect of $\mathrm{BC}$ on culture media temperature so this is probably not the factor that enhanced shoot and root growth and development. No ethylene emission was found in vials containing only WPM and $\mathrm{BC}$, and lower ethylene concentration after 14 and 21 days in vials with shoots grown on WPM with BC added than controls. But those results require extensive validation before the use of $\mathrm{BC}$ can become accepted practice. The identification of the most effective $\mathrm{BC}$ types and their subsequent standardization are certainly the most critical aspects that must be properly addressed. Even BC made from the same type of feedstock can in fact be very different depending on the production conditions as well as on the quality of the biomass (Uchimiya et al. 2011). The advent of new biomass gasification technologies that produce $\mathrm{BC}$ in a standardized process (De Pasquale et al. 2012) can certainly contribute towards adequate standardization, but the commercialization of BC stocks suitable for routine in vitro culture techniques will require the use of simple but robust analytical procedures to assess its mean porosity and the associated variability. Nitrogen adsorption tests and electron microscopy have already been successfully used to determine BC porosity (Sun H et al. 2012a, b) and Fast Field Cycling Nuclear Magnetic Resonance Relaxometry (FFC-NMR) is also very promising (Anoardo et al. 2001). We can conclude that (1) BC can be used in in vitro cultures at least for white poplar and can therefore replace $\mathrm{AC}$ which is certainly a much more expensive product, once biochar with a uniform quality can be guaranteed, (2) the feedstock and pyrolisis temperature are of importance in biochar production if ethylene absorption is required and (3) potential interactions must be elucidated between VOCs emissions and plant growth in in vitro cultures using biochar.

Acknowledgments We wish to sincerely thank Dr. Carla Benelli, Dr. Anna De Carlo and Dr. Elif Aylin Ozudogru from the Trees and Timber Institute of the National Research Council (IVALSA-CNR) for their personal support and valuable technical assistance for ethylene analysis. We owe special thanks to Dr. Luisa Andrenelli and Dr. Adriano Pasqualino Baglio for biochar and activated charcoal analysis. This research was supported by the EuroChar project (FP7-ENV2010 ID-265179).

\section{References}

Abeles FB, Morgan PW, Saltveit ME, Mikal E (1992) Ethylene in plant biology, 2nd edn. Academic Press, New York

Anagnostakis SL (1974) Haploid plants from anthers of tobaccoenhancement with charcoal. Planta 115:281-283

Andrade GM, Merkle SA (2005) Enhancement of American chestnut somatic seedling production. Plant Cell Rep 24:326-334

Anoardo E, Galli G, Ferrante G (2001) Fast-field-cycling NMR: applications and instrumentation. Appl Magn Reson 20:365-404

Baldwin IT, Halitschke R, Paschold A, von Dahl CC, Preston CA (2006) Volatile signaling in plant-plant interactions: "talking trees" in the genomics era. Science 311:812-815

Baronti S, Alberti G, Delle Vedove G, Di Gennaro F, Fellet G, Genesio L, Miglietta F, Peressotti A, Vaccari FP (2010) The biochar option to improve plant yields: first results from some field and pot experiments in Italy. Ital J Agron 5:3-11

Beesley L, Marmiroli M (2011) The immobilization and retention of soluble arsenic, cadmium and zinc by biochar. Environ Pollut 159(2):474-480 
Blackwell P, Riethmuller G, Collins M (2009) Biochar application to soil. In: Lehmann J, Joseph S (eds) Biochar for environmental management: science and technology. Earthscan, London, pp 207-226

Bon M-C, Gendraud M, Franclet A (1988) Roles of phenolic compounds on micropropagation of juvenile and mature clones of Sequoiadendron giganteum: influence of activated charcoal. Sci Hort 34:283-291

Borchard N, Prost K, Kautz T, Moeller A, Siemens J (2012) Sorption of copper (II) and sulphate to different biochars before and after composting with farmyard manure. Eur J Soil Sci 63(3):399-409

Buchheim JA, Colburn SM, Ranch JP (1989) Maturation of soybean somatic embryos and the transition to plantlet growth. Plant Physiol 89:768-775

Cao X, Ma L, Gao B, Harris W (2009) Dairy-manure derived biochar effectively sorbs lead and atrazine. Environ Sci Technol 43(9):3285-3291

Chan KY, Van Zwieten L, Meszaros I, Downie A, Joseph S (2007) Agronomic values of greenwaste biochar as a soil amendment. Aust J Soil Res 45:629-634

Confalonieri M, Balestrazzi A, Bisoffi S, Carbonera D (2003) In vitro culture and genetic engineering of Populus spp.: synergy for forest tree improvement. Plant Cell Tiss Org 72:109-138

De Pasquale C, Marsala V, Berns AE, Valagussa M, Pozzi A, Alonzo G, Conte P (2012) Fast field cycling NMR relaxometry characterization of biochars obtained from an industrial thermochemical process. J Soils Sediments 12(8):1211-1221

Dumas E, Monteuuis O (1995) In vitro rooting of micropropagated shoots from juvenile and mature Pinus pinaster explantsinfluence of activated charcoal. Plant Cell Tiss Org 40:231-235

El-Hendawy AA, Samra SE, Girgis BS (2001) Adsorption characteristics of activated carbons obtained from corncobs. Colloid Surf A 180:209-221

Firoozabady E, Heckert M, Gutterson N (2006) Transformation and regeneration of pineapple. Plant Cell Tiss Org 84:1-16

Fridborg G, Eriksson T (1975) Effects of activated charcoal on growth and morphogenesis in cell cultures. Physiol Plant 34:306-308

Fridborg G, Pedersén M, Landström L-E, Eriksson T (1978) The effect of activated charcoal on tissue cultures: adsorption of metabolites inhibiting morphogenesis. Physiol Plant 43:104-106

Gaskin JW, Speir RA, Harris K, Das KC, Lee RD, Morris LA, Fisher DS (2010) Effect of peanut hull and pine chip biochar on soil nutrients, corn nutrient status, and yield. Agron J 102:623-633

Guerro M, Ruzi MP, Alzuet MU, Bilbao R, Miller A (2005) Pyrolysis of eucalyptus at different heating rates: studies of char characterization and oxidative reactivity. J Anal Appl Pyrolysis 74:307-314

Guzmán P, Ecker JR (1990) Exploiting the triple response of Arabidopsis to identify ethylene-related mutants. Plant Cell 2:513-523

Hale SE, Hanley K, Lehmann J, Zimmerman A, Cornelissen G (2011) Effects of chemical, biological, and physical aging as well as soil addition on the sorption of pyrene to activated carbon and biochar. Environ Sci Technol 45(24):10445-10453

Hemphill JK, Maier CGA, Chapman KD (1998) Rapid in vitro plant regeneration of cotton (Gossypium hirsutum L.). Plant Cell Rep 17:273-278

Horner M, McComb JA, McComb AJ, Street HE (1977) Ethylene production and plantlet formation by Nicotiana anthers cultured in the presence and absence of charcoal. J Exp Bot 28: $1365-1372$

Johansson L (1983) Effects of activated charcoal in anther cultures. Physiol Plant 59:397-403

Johansson L (1986) Improved methods for induction of embryogenesis in anther cultures of Solanum tuberosum. Potato Res 29:179-190
Johansson L, Eriksson T (1977) Induced embryo formation in anther culture of several Anemone species. Physiol Plant 40:172-174

Johansson L, Andersson B, Eriksson T (1982) Improvement of anther culture technique: activated charcoal bound in agar medium in combination with liquid medium and elevated $\mathrm{CO}_{2}$ concentration. Physiol Plant 54:24-30

Johansson L, Calleberg E, Gedin A (1990) Correlations between activated charcoal, Fe-EDTA and other organic media ingredients in cultured anthers of Anemone canadensis. Physiol Plant 80:243-249

Joy RW, Kumar PP, Thorpe TA (1991) Long-term storage of somatic embryogenic white spruce tissue at ambient temperature. Plant Cell Tiss Org 25:53-60

Kimetu JM, Lehmann J, Ngoze SO, Mugendi DN, Kinyangi JM, Riha S, Verchot L, Recha JW, Pell AN (2008) Reversibility of soil productivity decline with organic matter of differing quality along a degradation gradient. Ecosystems 11:726-739

Kloepper JW, Ryu C-M, Zhang S (2004) Induced systemic resistance and promotion of plant growth by Bacillus spp. Phytopathology 94:1259-1266

Kookana RS (2010) The role of biochar in modifying the environmental fate, bioavailability, and efficacy of pesticides in soils: a review. Aust J Soil Res 48(7):627-637

Kuzyakov Y, Subbotina I, Chen H, Bogomolova I, Xu X (2009) Black carbon decomposition and incorporation into soil microbial biomass estimated by ${ }^{14} \mathrm{C}$ labeling. Soil Biol Biochem 41(2): 210-219

Laura M, Safaverdi G, Allavena A (2006) Androgenetic plants of Anemone coronaria derived through anther culture. Plant Breeding 125:629-634

Lehmann J (2007) Bio-energy in the black. Front Ecol Environ $5: 381-387$

Lehmann J, Joseph S (2009) Biochar for environmental management: science and technology. Earthscan, London

Lehmann J, Rondon M (2006) Biochar soil management on highly weathered soils in the humid tropics. In: Uphoff $\mathrm{N}$ (ed) Biological approaches to sustainable soil systems. CRC Press, Boca Raton, pp 517-530

Lehmann J, Da Silva JP Jr, Steiner C, Nehls T, Zech W, Glaser B (2003) Nutrient availability and leaching in an archaeological Anthrosol and a Ferralsol of the Central Amazon basin: fertilizer, manure and charcoal amendments. Plant Soil 249:343-357

Lehmann J, Skjemstad JO, Sohi S, Carter J, Barson M, Falloon P, Coleman K, Woodbury P, Krull E (2008) Australian climate-carbon cycle feedback reduced by soil black carbon. Nat Geosci 1:832-835

Liang B, Lehmann J, Solomon D, Sohi S, Thies JE, Skjemstad JO, Luizão FJ, Engelhard MH, Neves EG, Wirick S (2008) Stability of biomass-derived black carbon in soils. Geochim Cosmochim Ac 72:6078-6096

Lloyd G, McCown BH (1980) Commercially feasible micropropagation of mountain laurel Kalmia latifolia by use of shoot-tip culture. Comb Proc Int Plant Propag Soc 30:421-427

Loc NH, Duc DT, Kwon TH, Yang MS (2005) Micropropagation of zedoary (Curcuma zedoaria Roscoe) - a valuable medicinal plant. Plant Cell Tiss Org 81:119-122

Major J, Lehmann J, Rondon M, Goodale C (2010) Fate of soilapplied black carbon: downward migration, leaching and soil respiration. Glob Change Biol 16(4):1366-1379

Mensuali-Sodi A, Panizza M, Serra G, Tognoni F (1993) Involvement of activated charcoal in the modulation of abiotic and biotic ethylene levels in tissue-cultures. Sci Hortic 54:49-57

Miller RO (1998) Nitric-perchloric acid digestion in an open vessel. In: Kalra YP (ed) Handbook of reference methods for plant analysis. CRC Press, New York, pp 57-61

Misson JP, Boxus P, Coumans M, Giot-Wirgot P, Gaspar T (1983) Rôle du charbon de bois dans les milieux de culture de tissus végétaux. Med Fac Landbouww Rijksuniv Gent 48:1151-1157 
Mohamed-Yasseen Y (1994) Application of charcoal in horticulture. Tropical Fruit News 28:7

Mohamed-Yasseen Y (2001) Influence of agar and activated charcoal on uptake of gibberellin and plant morphogenesis in vitro. In Vitro Cell Dev Biol Plant 37:204-205

Mohamed-Yasseen Y, Barringer SA, Schloupt RM, Splittstoesser WE (1995) Activated charcoal in tissue culture: an overview. PGRSA Q 23:206-213

Noguera D, Rondon M, Laossi KR, Hoyos V, Lavelle P, Cruz de Carvalho MH, Barot S (2010) Contrasted effect of biochar and earthworms on rice growth and resource allocation in different soils. Soil Biol Biochem 42:1017-1027

Nomizu T, Niimi Y, Han DS (2004) Haploid plant regeneration via embryogenesis from anther cultures of Hepatica nobilis. Plant Cell Tiss Org 79:307-313

Oleszczuk P, Hale SE, Lehmann J, Cornelissen G (2012) Activated carbon and biochar amendments decrease pore-water concentrations of polycyclic aromatic hydrocarbons (PAHs) in sewage sludge. Bioresource Technol 111:84-91

Pan MJ, Van Staden J (1998) The use of charcoal in in vitro culturea review. Plant Growth Regul 26:155-163

Park JH, Choppala GK, Bolan NS, Chung JW, Chuasavathi T (2011) Biochar reduces the bioavailability and phytotoxicity of heavy metals. Plant Soil 348:439-451

Peck DE, Cumming BG (1986) Beneficial effects of activated charcoal on bulblet production in tissue cultures of Muscari armeniacum. Plant Cell Tiss Org 6:9-14

Rondon MA, Lehmann J, Ramírez J, Hurtado M (2007) Biological nitrogen fixation by common beans (Phaseolus vulgaris L.) increases with biochar additions. Biol Fert Soils 43:699-708

Ryu C-M, Farag MA, Hu C-H, Reddy MS, Wei H-X, Paré PW, Kloepper JW (2003) Bacterial volatiles promote growth in Arabidopsis. Proc Natl Acad Sci USA 100:4927-4932

Sensöz S (2003) Slow pyrolysis of wood barks from Pinus brutia Ten. and product compositions. Biores Technol 89:307-311

Simms EL, Rausher MD (1987) Costs and benefits of plant resistance to herbivory. Am Nat 130:570-581

Sinclair K, Slavich P, van Zwieten L, Downie A (2008) Productivity and nutrient availability on a Ferrosol: biochar, lime and fertiliser. In: Proceedings of the Australian Society of Agronomy Conference, Adelaide

Smith JL, Collins HP, Bailey VL (2010) The effect of young biochar on soil respiration. Soil Biol Biochem 42(12):2345-2347

Song Y, Wang F, Bian Y, Kengara FO, Jia M, Xie Z, Jiang X (2012) Bioavailability assessment of hexachlorobenzene in soil as affected by wheat straw biochar. J Hazard Mater 217-218:391397

Sopeña F, Semple K, Sohi S, Bending G (2012) Assessing the chemical and biological accessibility of the herbicide isoproturon in soil amended with biochar. Chemosphere 88(1):77-83

Spokas KA, Baker JM, Reicosky DC (2010) Ethylene: potential key for biochar amendment impacts. Plant Soil 333:443-452

Spokas KA, Novak JM, Stewart CE, Cantrell KB, Uchimiya M, Dusaire MG, Ro KS (2011) Qualitative analysis of volatile organic compounds on biochar. Chemosphere 85:869-882

Steiner C, Glaser B, Teixeira WG, Lehmann J, Blum WEH, Zech W (2008) Nitrogen retention and plant uptake on a highly weathered central Amazonian Ferralsol amended with compost and charcoal. J Plant Nutr Soil Sci 171:893-899

Sul III-W, Korban SS (2004) Effects of salt formulations, carbon sources, cytokinins, and auxin on shoot organogenesis from cotyledons of Pinus pinea L. Plant Growth Regul 43:197-205

Sul III-W, Korban SS (2005) Direct shoot organogenesis from needles of three genotypes of Sequoia sempervirens. Plant Cell Tiss Org $80: 353-358$
Sun K, Keiluweit M, Kleber M, Pan Z, Xing B (2011a) Sorption of fluorinated herbicides to plant biomass-derived biochars as a function of molecular structure. Bioresource Technol 102:98979903

Sun K, Ro K, Guo M, Novak J, Mashayekhi H, Xing B (2011b) Sorption of bisphenol A, 17a-ethinyl estradiol and phenanthrene on thermally and hydrothermally produced biochars. Bioresource Technol 102:5757-5763

Sun K, Gao B, Ro KS, Novak JM, Wang Z, Herbert S, Xing B (2012a) Assessment of herbicide sorption by biochars and organic matter associated with soil and sediment. Environ Pollut 163:167-173

Sun H, Hockaday WC, Masiello CA, Zygourakis K (2012b) Multiple controls on the chemical and physical structure of biochars. Ind Eng Chem Res 51:3587-3597

Thomas TD (2008) The role of activated charcoal in plant tissue culture. Biotechnol Adv 26:618-631

Uchimiya M, Wartelle LH, Klasson KT, Fortier CA, Lima IM (2011) Influence of pyrolysis temperature on biochar property and function as a heavy metal sorbent in soil. J Agric Food Chem 59(6):2501-2510

Uchimiya M, Wartelle LH, Boddu VM (2012) Sorption of triazine and organophosphorus pesticides on soil and biochar. J Agric Food Chem 60(12):2989-2997

USEPA (1995) Microwave assisted acid digestion of siliceous and organically based matrices. In: US environmental protection agency (ed) Test methods for evaluating solid waste. Washington, http://www.epa.gov/osw/hazard/testmethods/sw846/ pdfs/3052.pdf

Vaccari FP, Baronti S, Lugato E, Genesio L, Castaldi S, Fornasier F, Miglietta F (2011) Biochar as a strategy to sequester carbon and increase yield in durum wheat. Eur J Agron 34:231-238

Van Zwieten L, Kimber S, Sinclair K, Chan KY, Downie A (2008) Biochar: potential for climate change mitigation, improved yield and soil health. In: Proceedings of the New South Wales Grassland Conference, Tamworth

Vishnevetsky J, Zamski E, Ziv M (2003) Enhanced bud and bulblet regeneration from bulbs of Nerine sarniensis cultured in vitro. Plant Cell Rep 21:645-650

Wang H, Lin K, Hou Z, Richardson B, Gan J (2010) Sorption of the herbicide terbuthylazine in two New Zealand forest soils amended with biosolids and biochars. J Soils Sediments 10:283-289

Weatherhead MA, Burdon J, Henshaw GG (1978) Some effects of activated charcoal as an additive to plant tissue culture media. Z Pflanzenphysiol 89:141-147

Woolf D, Amonette JE, Street-Perrott FA, Lehmann J, Joseph S (2010) Sustainable biochar to mitigate global climate change. Nat Commun 1:56

Yamato M, Okimori Y, Wibowo IF, Anshori S, Ogawa M (2006) Effects of the application of charred bark of Acacia mangium on the yield of maize, cowpea and peanut, and soil chemical properties in South Sumatra. Indonesia Soil Sci Plant Nutr 52:489-495

Zaghmout OMF, Torello WA (1988) Enhanced regeneration in longterm callus cultures of red fescue by pretreatment with activated charcoal. HortScience 23:615-616

Zhang H, Kim M-S, Krishnamachari V, Payton P, Sun Y, Grimson M, Farag M, Ryu C-M, Allen R, Melo I, Paré P (2007) Rhizobacterial volatile emissions regulate auxin homeostasis and cell expansion in Arabidopsis. Planta 226:839-851

Zouine J, El Bellaj M, Meddich A, Verdeil JL, Hadrami IE (2005) Proliferation and germination of somatic embryos from embryogenic suspension cultures in Phoenix dactylifera. Plant Cell Tiss Org 82:83-92 